\title{
PENDAPAT IMAM SYĀFI'Ī TENTANG PENANGGUHAN HARTA WARISAN ORANG HILANG (Studi Kitab al-Umm)
}

\author{
Faslul Rahman \\ Universitas Maulana Malik Ibrahim Malang \\ r_faslul@yahoo.co.id
}

\begin{abstract}
Abstrak
Penelitian ini dilatarbelakangi atas perbedaan pendapat Imam Syāfı'ī dan Imam mazhab lainnya mengenai warisan orang hilang. Para ulama berbeda pendapat sampai kapan penangguhan dilakukan, apakah ditetapkan berdasarkan perkiraan waktu saja atau diserahkan kepada ijtihad hakim. Ada dua pertimbangan hukum dapat digunakan dalam mencari kejelasan status hukum orang yang hilang ini. Melalui teknik analisis data yang mencakup content analysis (analisis isi), pendapat Imam Syāfı'ì tentang warisan orang hilang yaitu hartanya tidak boleh dibagikan terlebih dahulu sebelum diketahui dengan yakin oleh ijtihad hakim di setiap tempat akan meninggalnya orang hilang tersebut.
\end{abstract}

\section{Kata Kunci:Penangguhan Harta Warisan, Mafqud.}

\section{A. Pendahuluan}

Hukum kewarisan dalam Islam mendapat perhatian besar, karena pembagian warisan sering menimbulkan akibat-akibat yang tidak menguntungkan bagi keluarga yang ditinggal mati pewarisnya. Naluriah manusia yang menyukai harta benda tidak jarang memotivasi seseorang untuk menghalalkan berbagai cara untuk mendapatkan harta benda tersebut, termasuk di dalamnya terhadap harta yang peninggalan harta pewarisnya sendiri. Kenyataan demikian telah ada dalam sejarah umat manusia hingga sekarang ini. Terjadinya kasus-kasus gugat waris di pengadilan agama maupun pengadilan negeri menunjukkan fenomena ini ${ }^{1}$

Hukum kewarisan sebagai satu pernyataan tekstual yang tercantum dalam al-Qur'ān merupakan suatu hal yang absolut dan universal bagi setiap Muslim untuk mewujudkan dalam kehidupan sosial. Sebagai ajaran yang universal, hukum kewarisan Islam mengandung nilai-nilai abadi dan unsur yang berguna untuk senantiasa siap mengatasi segala kesulitan sesuai dengan kondisi ruang dan waktu²

عن ابن عباس رضي الله عنه قال: قال رسول الله صلى الله عليه و سلم أقسموا المال بين أهل الفرائض على كتاب الله. (رواه

Artinya: Dari Abbās r.a berkata, Rasulullah s.a.w bersabda:"Bagikanlah harta pusaka antara ahli waris menurut kitabullah (al-Qur'ān)”. (HR. Muslim).

Hadis di atas menjelaskan betapa pentingnya al-Qur'an sebagai sumber

${ }^{1}$ Ahmad Rofiq, Hukum Islam di Indonesia, (Jakarta: PT Grafindo, 1998), Cet. Ke-3, h. 355

2 Idris Djakfar. Kompilasi Hukum Kewarisan Islam, (Jakarta: PT Dunia Pustaka Jaya, 1995), Cet. Ke-1, h. 1. 
dalam hukum warisan, namun demikian masih terdapat masalah-masalah mengenai hukum waris yang tidak tercantum dalam al-Qur'ān sehingga menimbulkan perbedaan pendapat dikalangan ahli hukum fikih, diantaranya adalah warisan orang yang hilang (mafqūd).

Pusaka orang yang hilang (mafqūd) ialah pusaka-mempusakai terhadap orang yang sudah lama pergi meninggalkan tempat tinggalnya, tidak diketahui kabar beritanya, domisilinya, dan matinya, yaitu apakah orang itu masih hidup atau sudah meninggal dunia ${ }^{3}$

Para ulama sepakat menetapkan bahwa harta dari pewaris yang hilang ditahan dulu sampai ada berita yang jelas.Namun, para ulama berbeda pendapat sampai kapan penangguhan dilakukan, apakah ditetapkan berdasarkan perkiraan waktu saja atau diserahkan kepada ijtihad hakim. Ada dua pertimbangan hukum dapat digunakan dalam mencari kejelasan status hukum orang yang hilang ini, diantaranya; Berdasarkan bukti-bukti autentik yang dapat diterima secara syarīah Islam, misalnya putusan tersebut berdasarkan persaksian dari orang yang adil lagi terpercaya. Jika demikian hal nya, maka simafqūd sudah hilang status mafqūdnya, ia ditetapkan seperti orang yang mati haqiqi sejak diputuskan; Berdasarkan batas waktu lamanya kepergian4.

Untuk menentukan hidup atau matinya orang yang hilang, para ulama berbeda pendapat: Imam Abū Hanīfah berpendapat bahwa seseorang yang hilang dianggap sudah meninggal dunia diukur dengan jangka waktu harus melewati waktu 90 tahun atau melihat teman sebayanya yang ada di tempat itu sudah mati, dan penetapan kematiannya itu hanya dapat dilakukan oleh lembaga pengadilan; menentukan tenggang waktu yang dijadikan ukuran seseorang yang hilang tersebut masih dalam keadaan masih hidup atau sudah mati, Imam Syāfı'ī menjelaskan dari pendapatnya Umar ibn Khațțāb bahwa tenggang waktu yang diperbolehkan untuk memberikan vonis kematian kepada si Mafqūd ialah 4 tahun, maka dengan adanya keputusan hakim tersebut harta si Mafqūd itu boleh dibagikan kepada ahli warisnya sesuai dengan ketentuannya. Pendapat ini beliau istinbațkan dari perkataan Sayyidina Umar r.a dalam kitab al-Umm sebagai berikut:

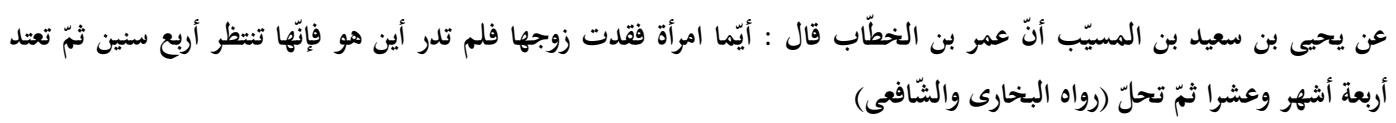

Artinya: Dari Yahyā bin Sa'id bin Musayyab bahwasanya Umar bin Khațtāb berkata; setiap perempuan yang ditinggalkan pergi oleh suaminya yang

3 Fatchur Rahman, Ilmu Waris, (Bandung: PT Al-Ma'arif, 1981), h. 504.

${ }^{4}$ Idris Djakfar. Kompilasi Hukum Kewarisan Islam, h. 52. 
tiada mengetahui di mana suaminya, maka ia diminta menanti 4 (empat) tahun. Kemudian setelah itu beriddah 4 bulan 10 hari dan kemudian ia menjadi halal (HR. Bukhāri dan Syāfi'īi) 5

Imam Mālik berpendapat bahwa menganggap orang yang hilang itu wafat, dalam hal yang berhubungan dengan hartanya adalah pada umur kebanyakan manusia, yaitu 70 tahun. Hal ini didasarkan pada hadis:

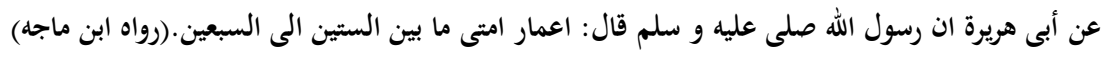

Artinya: Dari Abū Hurairah, bahwasanya Rasulullah s.a.w bersabda: "umur umatku antara enam puluh sampai tujuh puluh (tahun)”. (HR. Ibnu Mājah)6

Orang yang hilang menurut situasi dan kebiasaannya ia akan binasa (seperti waktu peperangan, tenggelam waktu pelayaran atau pesawat jatuh dan temannya ada yang selamat), maka orang yang hilang harus diselidiki selama 4 tahun, jika tidak ada kabar beritanya, maka hartanya sudah dapat dibagi, pendapat ini dipegang oleh ulama-ulama Hanabilah. Sedangkan apabila kehilangan tersebut bukan disebabkan oleh peristiwa yang membawa kematian (seperti pergi berdagang atau merantau) ulama Hanabilah berbeda pendapat, yaitu; menunggu sampai 90 tahun sejak ia dilahirkan atau diserahkan kepada ijtihad hakim.

Menurut ketentuan ilmu ushul fikih, harta bagi orang yang Mafqūd yang belum ditentukan orang ini meninggal dunia atau hidup, masih tetap belum boleh diwarisi, karena orang itu masih dipandang hidup. Sehingga hartanya masih tetap miliknya.Lain halnya kalau orang tadi dinyatakan meninggal dunia oleh hakim berdasarkan bukti-bukti yang kuat, maka hartanya dapat dibagikan kepada ahli warisnya yang berhak.Ahli waris yang berhak itu ahli waris yang masih hidup pada waktu orang yang Mafqūd itu meninggal dunia.

\section{B. Metode Penelitian}

Jenis penelitian yaitu penelitian kepustakaan (library research) dengan mempelajari dan menelaah bahan-bahan tertulis, seperti buku, majalah, jurnal, skripsi, dan sumber data yang terkait dengan pendapat Imam Syāfi'ì dalam kitab alUmm.Penelitian ini bersifat studi literatur, yaitu dengan mempelajari, menelaah dan mengkaji buku-buku yang diperoleh dari perpustakaan.Sehingga memperoleh datadata yang diperlukan.

Dalam penelitian ini sumber data primer yaitu data yang diambil berkaitan dengan judul dan pembahasan ini, yakni kitab al-Umm yang dikarang oleh Imam Syāfı'ī. Sumber data sekunder, yaitu data yang mendukung sumber primer, yakni

${ }^{5}$ Muhammad bin Idris Asy-Syafi'i, Al-Umm, (Beirut: Daar al-Wafa, 2001), Jilid 5, h. 153-154.

6 Ibnu Majah, Sunan Ibnu Majah, (Beiirut: Darul Fikri, 1992), h. 1415. 
dari buku-buku seperti Minhājul Muslim, Bidayatul Mujtahīd, skripsi, jurnal, dan sumber informasi yang akurat dan dapat dipertanggungjawabkan. Sumber Data Tersier yakni terdiri dari kamus dan ensiklopedi.

Sementara itu, metode analisis data yang digunakan Content Analisis, yaitu menganalisis data dalam upaya relevan sebagai dasar bagi peneliti untuk mengkaji teori dan mencari hubungan content fungsional dengan tema penelitian.

\section{Kajian Pustaka}

\section{Kewarisan Orang Hilang}

Orang hilang adalah seseorang yang lama hilang tidak diketahui keadaannya sehingga tidak diketahui apakah dia masih hidup atau sudah mati. Penjelasan mengenai orang hilang terdapat dua sisi $^{7}$

a. Orang lain mewarisi harta orang hilang; Terkadang, orang yang hilang, namun apakah harta itu boleh diwarisi atau tidak? Asal hukumnya, orang yang hilang masih dianggap hidup, jika dihubungkan dengan hartanya. Oleh karena itu harta yang ditinggalkan masih tetap menjadi miliknya dan harus dipelihara sampai keberadaan orang yang bersangkutan jelas. Apabila dia kembali dalam keadaan hidup, sebelum hakim memutuskan kematiannya, harta tersebut harus diserahkan kepadanya. Kalau ada yang mengambil hartanya tanpa hak, orang yang mengambil itu harus mengembalikan atau menggantinya. Apabila kematiannya sudah jelas dan ada buktinya atau ada surat-surat resmi yang menegaskan kematiannya, kematiannya itu adalah kematian yang hakiki. Oleh sebab itu, ahli warisnya boleh mewarisi terhitung mulai tanggal kematiannya. Namun, jika tidak diketahui hidup atau matinya, dan keadaan itu terus berlanjut, harta yang ditinggalkannya tetap menjadi miliknya sampai ada keputusan dari hakim yang berhak mengeluarkan keputusan atau kematiannya.

b. Orang hilang mewarisi harta orang lain; Apabila orang yang hilang belum diketahui secara pasti, apakah ia masih hidup atau sudah mati, tidak dapat diputuskan bahwa ia tidak dapat mewarisi karena ada kemungkinan ia masih hidup atau sudah meninggal, dan tidak dapat diputuskan bahwa ia dapat mewarisi karena ada kemungkinan ia sudah meninggal. Oleh karena itu, pembagian harta waris harus ditangguhkan sampai keberadaan orang hilang diketahui. Adapun kemungkinan-kemungkinan orang yang hilang sebagai berikut:

7 Muhammad Muhyidin, Panduan Waris Empat Madzhab, (Pustaka Al-Kautsar 2009), Cet. Ke 1, 
1) Apabila orang yang hilang diketahui masih hidup, ia boleh mengambil haknya dari harta waris yang ditangguhkan pembagiannya

2) Apabila orang hilang diketahui telah wafat setelah muwarris meninggal dan ada bukti yang dapat diterima syara', harta yang ditinggalkannya dan bagian atas harta waris digabungkan, kemudian dibagikan kembali untuk ahli warisnya yang masih hidup.

3) Apabila bukti yang dapat diterima syara', jelas menyebutkan bahwa orang yang hilang meninggal sebelum muwarris wafat, orang yang hilang itu tidak berhak mendapatkan apa-apa dari harta waris yang ditangguhkan pembagiannya. Kemudian, harta waris yang ditangguhkan pembagiannya dibagikan untuk ahli waris lain, dan harta yang ditinggalkan oleh orang yang hilang itu diserahkan kepada ahli warisnya untuk dibagikan.

4) Apabila orang yang hilang tidak diketahui dengan pasti kapan kematiannya, sebelum atau sesudah muwarris wafat, dia tidak dapat mewarisi karena masih ada keraguan di sana.

5) Apabila hakim memutuskan berdasarkan perkiraan yang kuat bahwa orang yang hilang meninggal, orang itu dianggap meninggal terhitung sejak ia hilang. Oleh karena itu, ia tidak dapat mewarisi harta yang ditangguhkan pembagiannya, dan semuanya dikembalikan kepada ahli waris.

Sementara itu, ahli waris yang hidup ketika seseorang hilang, mendapatkan bagian yang paling kecil dari dua kemungkinan cara menghitung pembagian harta waris, sampai keberadaan orang yang hilang itu jelas. Adapun kemungkinan-kemungkinan kondisi yang dihadapi ahli waris itu ada tiga, yakni sebagai berikut:

1) Dapat mewarisi dalam satu kondisi dan tidak mewarisi dalam kondisi yang lain. Oleh karena itu, ahli waris yang demikian tidak mendapatkan apa-apa.

2) Bagian warisannya tidak berubah-ubah atau tidak terpengaruh, ketika orang yang hilang itu masih hidup atau sudah meninggal. Ahli waris yang demikian mendapatkan bagiannya secara sempurna.

3) Bagian warisannya berubah-ubah atau terpengaruh, ketika orang yang hilang itu masih hidup atau sudah meninggal. Keadaan ini, ahli waris yang demikian diberikan bagiannya yang paling sedikit berdasarkan dua kemungkinan cara menghitung pembagian harta waris, sampai ada kejelasan tentang orang yang hilang itu.

\section{Keadaan Orang yang Hilang (Mafqūd)}

a. Keadaan Pertama 
Orang yang hilang diperkirakan selamat, diantaranya adalah orang yang hijrah ke negeri asing untuk mencari rezki, orang yang pergi bertamasya, berdagang atau menuntut ilmu. Kondisi yang demikian, tenggat waktu yang akan diputuskan oleh hakim mengenai kematiannya diserahkan kepada wali al-Amr atau orang yang mewakilkannya. Itu pun dilakukan setelah penyelidikan dan pencarian orang yang hilang, untuk mengetahui dengan pasti apakah ia masih hidup atau sudah meninggal, sudah dilakukan secara optimal.

\section{b. Keadaan Kedua}

Orang yang hilang diperkirakan tidak selamat atau meninggal, di antaranya adalah orang yang hilang di daerah yang tidak aman dan sering terjadi pembunuhan atau perampokan, orang yang pergi perang dan lainnya. Kondisi yang demikian, seluruh kerabatnya diharuskan menunggu selama empat tahun sejak orang itu hilang. Apabila dalam tenggat waktu itu tepat tidak ada kabar, hakim boleh memberikan keputusan mengenai kematiannya, dan orang itu dianggap meninggal sejak keputusan hakim ditetapkan.

\section{Cara Pembagian Harta Waris Ketika di antara Ahli Waris Ada yang Hilang}

Apabila dalam persoalan waris ada orang yang belum diketahui keberadaannya, masalah ini dapat diselesaikan dengan dua cara, karena ada dua kemungkinan. Pertama, orang yang hilang diperkirakan masih hidup, dan kedua, orang yang hilang diperkirakan sudah meninggal.

a. Contoh pertama; Ahli waris terdiri dari paman dan anak laki-laki yang hilang. Harta warisan sebesar Rp. 100 juta. Tentukan bagian mereka?

1) Jika mafqūd diperkirakan masih hidup.

Paman mahjub terhalang oleh anak.

Anak laki-laki ashabah 1 x 100 juta = Rp. 100 juta

2) Jika mafqūd diperkirakan sudah mati.

Paman așābah 1x 100 juta = Rp. 100 juta.

Anak laki-laki sudah mati.

oleh karena itu, menurut ketentuan, harta warisan belum dapat dibagikan sampai jelasnya wafatnya mafqūd

b. Contoh kedua; Ahli waris terdiri dari istri, ibu, dan saudara laki-laki sekandung yang hilang. Harta warisan sebesar Rp. 360 juta. Tentukan bagian mereka?

1) Jika mafqūd diperkirakan masih hidup.

Istri 1/4 karena tidak ada anak. 
Ibu 1/3 tidak ada anak dan saudara ada satu.

Saudara laki-laki sekandung așābah.

\begin{tabular}{|l|l|l|}
\hline Asal masalah & 12 & \\
\hline Istri & $1 / 4$ & $\begin{array}{l}3 / 12 \times 360 \text { juta } \\
=90 \text { juta }\end{array}$ \\
\hline Ibu & $1 / 3$ & $\begin{array}{l}4 / 12 \times 360 \text { juta } \\
=120 \text { juta }\end{array}$ \\
\hline $\begin{array}{l}\text { Saudara laki-laki } \\
\text { sekandung }\end{array}$ & Așōbah & $\begin{array}{l}5 / 12 \times 360 \text { juta } \\
=150 \text { juta }\end{array}$ \\
\hline
\end{tabular}

2) Jika mafqūd diperkirakan sudah meninggal

Istri 1/4 karena tidak ada anak.

Ibu 1/3 tidak ada anak dan saudara ada satu.

Saudara laki-laki sekandung așābah

\begin{tabular}{|l|l|l|}
\hline Asal masalah & 12 & $\begin{array}{l}3 / 12 \times 360 \text { juta } \\
=90 \text { juta }\end{array}$ \\
\hline Istri & $1 / 4$ & $\begin{array}{l}4 / 12 \times 360 \text { juta } \\
=120 \text { juta }\end{array}$ \\
\hline Ibu & $1 / 3$ & $\begin{array}{l}5 / 12 \times 360 \text { juta } \\
=150 \text { juta/tidak } \\
\text { dapat }\end{array}$ \\
\hline $\begin{array}{l}\text { Saudara laki-laki } \\
\text { sekandung }\end{array}$ & Așābah/Mati \\
\hline
\end{tabular}

Masalah ini menjadi radd.Sisanya itu berhak dimiliki ibu, karena istri tidak menerima radd.Oleh karena itu, harta warisan sebesar 150 juta harus ditahan sampai kepastian wafatnya jelas. Jika ternyata sudah mati, harta tersebut milik ibu.

\section{Pembahasan dan Hasil}

\section{Pendapat dan Istinbaț Imam Syāfı'ī tentang Penangguhan Harta Warisan Orang Hilang}

Sebelumnya telah peneliti jelaskan tentang pendapat Imam Syāfi'ī, yaitu warisan orang yang hilang (mafqūd), menurut Imam Syāfı'ī bahwa, orang yang hilang dalam waktu yang lama dan tidak diketahui kabar beritanya, apakah orang tersebut masih hidup atau sudah mati, maka orang tersebut harus dihukumi masih hidup sampai diketahui dengan pasti bahwa orang tersebut sudah mati, dan tidak boleh menghukumi kematian sesorang kecuali dengan yakin ${ }^{8}$

${ }^{8}$ Abi Hasan Ali, Al-Khaw Al-Kabir, (Baerut-Libanon: Darul Kutub Alamiah, tt), juz. 7, hlm. 88. 
Apabila belum diketahui dengan yakin tentang kematiannya, maka wajib menunda dulu kepemilikan hartanya sampai batas waktu yang telah ditentukan.Apabila masa tidak boleh memberikan penghidupan kepada Mafqūd sudah berlalu, maka hartanya dibagikan kepada ahli warisnya yang masih hidup. Jika ahli waris dari si mafqud itu sudah meninggal dunia, maka harta warisan Mafqūd itu harus ditunda sampai ada kejelasan tentang perkaranya; yaitu kalau dia itu masih hidup, ketika si Mafqūd mati, maka dia termasuk sebagai ahli waris dan jika ia sudah mati sebelum si Mafqūd itu mati, maka dia tidak termasuk ahli waris, sehingga begiannya diberikan kepada ahli waris yang lain.

Imam Syāfi'ì dalam kitab al-Umm menjelaskan bahwa tidak ada warisan sebelum orang yang mewarisi (pewaris) itu meninggal dunia.Apabila meninggal dunia, maka waris itu ada.Sebab orang hidup itu berbeda dengan orang mati. Mengenai orang hilang menurut Imam Syāfı'ı̄, hartanya tidak boleh dibagikan terlebih dahulu sebelum diketahui dengan yakin akan meninggalnya Mafqūd tersebut $^{9}$

Menentukan tenggang waktu yang dijadikan ukuran seseorang yang hilang tersebut masih dalam keadaan masih hidup atau sudah mati, Imam Syāfı̄i menjelaskan dari pendapatnya Umar ibn Khațāa bahwa tenggang waktu yang diperbolehkan untuk memberikan vonis kematian kepada si Mafqūd ialah 4 tahun. Maka dengan adanya keputusan hakim tersebut harta si Mafqūd itu boleh dibagikan kepada ahli warisnya sesuai dengan ketentuannya.

Hal ini sesuai dalam kitab al-Umm disebutkan:

عن يحيى بن سعيد بن المسيّب أنّ عمر بن الخطّاب قال : أيّما امرأة فقدت زوجها فلم تدر أين هو فِإنها تنظظر أربع سنين ثمّ تعتد

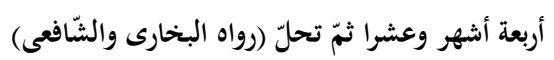

Artinya: Dari Yahyā bin Sa'īd bin Musayyab bahwasanya Umar bin Khațāa berkata; "Setiap perempuan yang ditinggalkan pergi oleh suaminya yang tiada mengetahui di mana suaminya, maka ia diminta menanti 4 (empat) tahun. Kemudian setelah itu beriddah 4 bulan 10 hari dan kemudian ia menjadi halal." (HR. Bukhāri danSyāfi'ī) ${ }^{10}$

Pada kitab Mugni Muhtaj disebutkan:

ومن أسر أو فقد وانقطع خبره ترك ماله حتّى تقوم بينة بموته أو تمضى مدّة يغلب على الظّّ أنّه فوقها فيجتهد القاضى و يحكم بموته ثمّ يعطى ماله من يرثه وقت الحكم

Artinya : "Orang yang ditahan atau orang yang putus kabar beritanya dan meninggalkan harta maka hartanya ditunda (tidak dibagi) sampai ada kejelasan tentang kematiannya atau dalam waktu yang lama sehingga diperkirakan sudah mati dan hakim telah memutuskan bahwa si mafqūd sudah mati kemudian hartanya

${ }_{9}^{9}$ Muhammad bin Idris Asy-Syafi'i, Al-Umm, (Beirut: Daar al-Wafa, 2001), juz 3, h. 78

10Ibid,, 
diberikan kepada ahli warisnya pada waktu terjadi hukum tersebut."11

Pada kitab ini dijelaskan pula:

ولو مات من يرثه المفقود وقفنا خصيّه وعملنا في الحاضرين بالأسواء ولو خلّف حملاً يرث أو قد يرث عمل بالأحوط في

حقّه وحقّ غيره

Artinya : "Apabila ahli waris orang yang menghilang itu meninggal, maka harta bagiannya ditangguhkan dulu dan memberikan dulu bagian dari ahli waris yang ada dengan sama (sesuai dengan ketentuannnya) dan apabila meninggalkan ahli waris dalam keadaan hamil, maka warisannya harus dibagi dengan hati-hati antara haknya orang yang hamil dengan hak anaknya."

Syarah dari matan di atas dijelaskan bahwa apabila seorang itu Mafqūd dengan putus kabar beritanya, maka hartanya harus ditunda (tidak dibagi) terlebih dahulu, sehingga ada tanda-tanda yang terang tentang meninggalnya dengan menghitung umurnya yang sudah berlalu mulai dari kelahirannya yang diperkirakan tidak akan hidup lagi di atas umur itu. Apabila begitu maka hartanya dapat diberikan kepada orang yang mempunyai haknya (ahli waris), apabila orang yang hilang itu meninggal sebelum ada tanda-tanda atau ketetapan hukum dari hakim, sekalipun tidak lama dari ketetapan itu, maka tidak boleh dibagikan warisan itu dari si Mafqūd itu, karena dia meninggal masih dalam zaman yang diperkirakan tadi.

Apabila ahli waris itu meninggal terlebih dahulu, maka harta bagiannya ditinggalkan dulu dan memberikan dulu bagian dari ahli waris yang lain dengan sama (sesuai dengan ketentuannya) dan apabila meninggalkan ahli waris dalam keadaan hamil, maka warisannya harus dibagikan dengan hati-hati antara haknya orang yang hamil dengan hak anak-anaknya.

Para fuqaha dalam kitab-kitab fikih telah menetapkan bahwa orang yang hilang (mafqūd) adalah orang yang putus kabar beritanya dalam waktu yang cukup lama, sehingga tidak diketahui apakah orang tersebut masih hidup atau sudah mati.Untuk menentukan kematiannya itu para ulama sepakat bahwa yang berhak menetapkan tentang kematian orang yang hilang itu adalah seorang hakim, akan tetapi jangka waktu yang dijadikan patokan hakim dalam menentukan putusan itu, ulama' mazhab mengalami perbedaan, sesuai dengan ijtihadnya masing-masing.

Menurut peneliti bahwa penentuan orang hilang (mafqūd) apakah ia masih hidup atau sudah mati lebih tepat dan lebih simpatik bila ia diserahkan kepada pendapat hakim, lebih-lebih pada zaman sekarang yang lebih mudah untuk mengetahui keadaan orang-orang yang hilang. Sebagaimana yang telah dijelaskan dalam kitab Mugni Muhtaj:

${ }^{11}$ Muhamad Syamsuddin, Mugni Muhtaj, (Beirut: Darul Kutub Alamiah, tt), juz, 4. h. 48. 
ومن أسر أو فقد وانقطع خبره ترك ماله حتّى تقوم بينة بموته اوتمضى مدّة يغلب على الظّن أنّه فوقها فيجتهد القاضى و يحكم بموته ثمّ يعطى ماله من يرثه وقت الحكم

Artinya : "Orang yang ditahan atau orang yang putus kabar beritanya dan meninggalkan harta maka hartanya ditunda (tidak dibagi) sampai ada kejelasan tentang kematiannya atau dalam waktu yang lama sehingga diperkirakan sudah mati dan hakim telah memutuskan bahwa si mafqūd sudah mati kemudian hartanya diberikan kepada ahli warisnya pada waktu terjadi hukum tersebut."

keterangan di atas, apabila seseorang yang hilang dalam waktu yang lama sehingga tidak jelas apakah ia masih hidup atau sudah mati, maka hartanya ditangguhkan terlebih dahulu sampai ada kepastian tentang kematiannya. Akan tetapi, penetapan kematiannya seseorang itu hanya dapat dilakukan oleh keputusan hakim (keputusan lembaga peradilan)12.Oleh karena itu seseorang yang hilang dalam waktu yang lama, menurut peneliti penetapan kematiannya seseorang itu hanya dapat dilakukan oleh keputusan hakim (keputusan lembaga peradilan) pendapat peneliti tersebut ternyata ada kesesuaian dengan ketentuan Mafqūd yang tercantum dalam Kompilasi Hukum Islam di Indonesia.

KHI Pasal 96 ayat 2 disebutkan: "Pembagian harta bersama bagi seorang suami atau istri yang istri atau suaminya hilang harus ditangguhkan sampai adanya kepastian matinya yang hakiki atau matinya secara hukum atas dasar putusan pengadilan agama"13

Adapun mengenai jangka waktu yang dapat dijadikan ukuran menentukan orang yang hilang tersebut sudah meninggal atau masih hidup, peneliti sependapat dengan pendapatnya Imam Syāfi'ī bahwa orang yang hilang (mafqūd) boleh diputuskan kematiannya oleh hakim setelah 4 tahun.

Imam Syāfı'ì berdalil dari perkataan Sayyidina Umar r.a yang mengatakan:

عن يحيى بن سعيد بن المسيّب أنّ عمر بن الخطّّب قال : أيّما امرأة فقدت زوجها فلم تدر أين هو فإنّها تنظظر أربع سنين ثمّ تعتد

Artinya: Dari Yahyā bin Sa'īd bin Musayyab bahwasanya Umar bin Khatțāb berkata; setiap perempuan yang ditinggalkan pergi oleh suaminya yang tiada mengetahui di mana suaminya, maka ia diminta menanti 4 (empat) tahun. Kemudian setelah itu beriddah 4 bulan 10 hari dan kemudian ia menjadi halal (HR. Bukhāri danSyāfı'ī)

Keterangan di atas, bahwa Imam Syāfı'ī membolehkan seorang hakim dalam memutuskan orang yang hilang (mafqūd) setelah 4 tahun.

12 Surawardi, Hukum Waris Islma, (Jakarta: Sinar Grafika, 1995), h. 64.

13 Abdurrahman, Kompilasi Hukum Islam di Indonesia, (Banjarmasin: Depag, 1992), h.136 


\section{Posisi Pendapat Imam Syāfi'ī tentang Penangguhan Harta Warisan Orang Hilang dalam Hukum Kewarisan Islam}

Menyangkut status hukum orang yang hilang ini para ahli hukum Islam menetapkan bahwa: Istri orang yang hilang tidak boleh dikawinkan; Harta orang yang hilang tidak boleh diwariskan; Hak-hak orang yang hilang tidak boleh dibelanjakan atau dialihkan.

Ketidakbolehan ketiga hal tersebut di atas sampai orang yang hilang tersebut diketahui dengan jelas statusnya, yaitu apakah ia dalam keadaan masih hidup atau sudah meninggal dunia. Dan apabila statusnya masih diragukan maka statusnya masih dianggap sebagai masih hidup sesuai dengan keadaan semula. Dan dapat ditambahkan, bahwa yang berhak untuk menentukan seseorang yang hilang sesudah mati hanyalah hakim ${ }^{14}$

Ada dua pertimbangan yang dapat digunakan oleh hakim dalam menentukan kejelasan status hukum kematian dari Mafqūd, yaitu:

a. Berdasarkan bukti-bukti autentik yang dapat dibenarkan syara' sebagai landasan untuk menentukan hukum kematian Mafqūd. Sebagaimana dalam kaidah uṣul fikih:

$$
\text { الثّابت بالبينة كالثّابت بالمعاينة }
$$

Artinya: Yang tetap berdasaran bukti bagaikan yang tetap berdasarkan kenyataan.

Jadi misalnya ada orang yang adil dan dapat dipercaya untuk memberikan kesaksian bahwa si fulan yang hilang (al-Mafqūd) telah meninggal dunia, maka hakim dapat menjadikan dasar persaksian tersebut untuk memutuskan status kematian al-Mafqūd.Ia ditetapkan seperti orang yang mati hakiki sejak diputuskan oleh hakim.

Pada kepastiannya sebagai al-Muwaris̉ jika hakim telah memutuskan hukum, maka harta kekayaannya dapat dibagi kepada ahli warisnya. Karena keputusan hakim yang telah mempunyai kekuatan hukum tetap perlu dihormati dan dilaksanakan ${ }^{15}$

b. Berdasarkan batas waktu lamanya kepergian al-Mafqūd. Pertimbangan dan upaya hukum demikian memang tidak cukup kuat secara hukum, akan tetapi sebagian dapat diterima dan mempunyai referensi atau acuan hukum sebagai berikut:

Imam Syāfı'ì berdalil dari perkataan Sayyidina Umar r.a yang mengatakan:

عن يحيى بن سعيد بن المسيّب أنّ عمر بن الخطّاب قال : أيّما امرأة فقدت زوجها فلم تدر أين هو فإنّها تنتظر أربع سنين ثمّ تعتد 


$$
\text { أربعة أشهر وعشرا ثمّ تحلّ (رواه البخارى والثّافعى) }
$$

Artinya: Dari Yahyā bin Sa'īd bin Musayyab bahwasanya Umar bin Khațāb berkata; setiap perempuan yang ditinggalkan pergi oleh suaminya yang tiada mengetahui di mana suaminya, maka ia diminta menanti 4 (empat) tahun. Kemudian setelah itu beriddah 4 bulan 10 hari dan kemudian ia menjadi halal (HR. Bukhāri danSyāfı'̄i).

Penjelasan di atas, untuk menetapkan status hukum al-Mafqūd, diserahkan kepada ijtihad hakim dalam memutuskan hukum.Sudah barang tentu dalam perspektif hukum formil, maka ahli waris yang mengajukan permohonan tentang status al-Mafqūd, mengingat posisi hakim adalah pasif.Artinya menunggu inisiatif dari pihak yang berperkara yaitu ahli waris yang ada dan berkepentingan dengan keberadaan al-Mafqūd.

Era informasi dan teknologi modern seperti sekarang ini, pertimbangan di atas perlu diteliti efektivitasnya kembali. Fasilitas penerangan baik melalui media cetak maupun media elektronik yang sudah tentu akan membantu tugas-tugas hakim dalam upaya menetapkan status pewaris yang hilang.

\section{Kesimpulan}

Imam Syāfı'ī berpendapat bahwa orang yang hilang (mafqūd) vonis kematiannya ditetapkan menurut ijtihad hakim di setiap tempat setelah menanti selama empat tahun demi suatu kemaslahatan. Imam Syāfı'ī menjelaskan pendapatnya berdasarkan ijtihad Umar ibn Khaț̣āb bahwa tenggang waktu yang diperbolehkan untuk memberikan vonis kematian Mafqūd ialah 4 tahun, karena dalam kasus ini sama sakali tidak terdapat aturan bakunya baik dalam al-Qur'ān maupun dalam hadis. Imam Syāfı'î berpendapat berdasarkan pada qaul sahabat, karena qaul sahabat merupakan hasil ijtihad yang secara sah dapat dijadikan contoh dalam menetapkan suatu hukum, karena tidak ada rujukan yang lain.

Posisi istinbaț Imam Syāfı'ì tentang penangguhan harta warisan orang hilang bisa diterima, sebab dalam hukum kewarisan Islam untuk menetapkan status hukum al-Mafqūd yaitu dengan diserahkan kepada ijtihad hakim dalam memutuskan hukum setelah adanya bukti-bukti dari orang-orang yang adil, terpercaya, dan juga dari fasilitas penerangan baik melalui media cetak maupun media elektronik. Hal ini sependapat dengan pendapat Imam Syāfı'ì bahwa orang yang hilang ( $m a f q u \bar{d}$ ) mengenai tetapnya istri dan hartanya walaupun dalam waktu yang sangat lama, sehingga berat sangkaan bahwa orang itu sudah mati, yaitu hakim dapat memberikan vonis kematian si Mafqūd berdasarkan bukti-bukti autentik yang dapat dibenarkan syara' sebagai landasan untuk menentukan hukum kematian Mafqūd. Maka dengan adanya keputusan hakim tersebut bahwa harta orang hilang itu boleh dibagikan kepada ahli warisnya sesuai dengan ketentuannya. 


\section{DAFTAR PUSTAKA}

Abdul Hamid, Muhammad Muhyidin, Panduan Waris Empat Mazhab, Pustaka alKautsar, 2009.

Abdurrahman, Kompilasi Hukum Islam di Indonesia, Banjarmasin: Depag, 1992.

Alī, Abi Hasan, Al- Khaw al-Kabìr. Baerut-Libanon: Darul Kutub Alamiah, tt

Komite Fakultas Syarī'ah Universitas Al-Azhār Mesir, Hukum Waris. Jakarta: Senayan Abadi Publishing, 2004

Lubis, Suhrawardi K, Komis Simanjutak. Hukum Waris Islam, Jakarta: Sinar Grafika, 1995.

Mājah, Ibnu. Sunnah Ibnu Mājah, Beirut: Darul Fikri, 1992.

asy- Syāfi'ī, Muhammad bin Idris. Al-Umm, Beirut: Daar al-Wafa, 2001.

Muhammad, Syamsuddin, Mugni Muhtaj, Beirut: Darul Kutub Alamiah, tt

Rahman, Fatchur. Ilmu Waris, Bandung: PT Al-Ma'rif, 1981

Rofiq, Ahmad. Hukum Islam di Indonesia. Jakarta: PT Grafindo, 1998.

Taufik Yahya, Idris Djakfar. Kompilasi Hukum Kewarisan Islam, Jakarta: PT Dunia Pustaka Jaya, 1995. 